\title{
PENGOLAHAN SAMPAH PLASTIK METODE CRACKING DI KELURAHAN KELAYU JORONG LOMBOK TIMUR
}

\section{PLASTIC WASTE PROCESSING WITH CRACKING METHOD IN KELAYU JORONG VILLAGE EAST LOMBOK}

\author{
Siti Raudhatul Kamali, Iwan Sumarlan, Fahrurazi
}

\author{
Program Studi Kimia, Fakultas Matematika dan Ilmu Pengetahuan Alam Universitas \\ Mataram. Jalan Majapahit No 62 Mataram 83125. Indonesia \\ Email: sitikamali@gmail.com
}

Diterima: : 5 Agustus 2017. Disetujui 10 September 2017. Dipublikasikan: 30 September 2017

\begin{abstract}
Abstrak. Telah dilakukan kegiatan alih teknologi pengolahan sampah plastik metode cracking di Kelurahan Kelayu Jorong, Lombok Timur. Alih teknologi yang dilakukan terdiri atas pengelolaan sampah rumah tangga khususnya sampah plastik yang dilanjutkan dengan pengolahan sampah plastik menggunakan metode cracking. Ada dua metode yang digunakan pada kegiatan, yakni pendekatan sosialisasi dan metode praktek pengolahan limbah plastik. Hasil yang diperoleh berupa peningkatan pemahaman tentang pengelolaan sampah rumah tangga yang ditandai dengan terampilnya masyarakat dalam melakukan pewadahan dan pemilahan sampah berdasarkan jenisnya. Pengolahan sampah plastik menggunakan metode cracking mendapat respon yang baik dari masyarakat mitra di Kelurahan Kelayu Jorong. Pengolahan sampah plastik menjadi bahan bakar cair berhasil dilakukan dengan komponen utama bahan bakar yang dihasilkan berupa bensin sebesar $58,81 \%$.
\end{abstract}

Kata kunci: sampah plastik, metode cracking, bahan bakar

\begin{abstract}
The transfer of plastic waste processing technology using cracking method has been done in kelurahan Kelayu Jorong, East Lombok. Plastic waste is obtained from household waste which is then processed using cracking method. This technology transfer activity uses socialization approach and plastic waste processing practice. The results obtained in the form of increased understanding of household waste management. This is characterized by the skill of the community in carrying out waste collection and sorting by type. Plastic waste processing activities using this cracking method received a good response from the Kelurahan Kelayu Jorong community. Plastic waste processing into liquid fuel has been successfully done with the main fuel component ie gasoline by $58.81 \%$.
\end{abstract}

Keywords: plastic waste, cracking method, fuels

\section{PENDAHULUAN}

Manusia dalam kegiatan sehari-hari tidak terlepas dari penggunaan plastik. Plastik habis pakai atau yang mengalami kerusakan tidak dimanfaatkan lagi oleh masyarakat dan dibuang menjadi sampah. Di sisi lain, pemakaian kantong plastik dan kemasan pmbungkus makanan juga berkontribusi sebagai penambah volume sampah di samping jenis-jenis sampah lainnya.

Sampah yang tidak dikelola dan dibiarkan terus-menerus akan menimbulkan berbagai dampak bagi manusia dan lingkungan sekitar. Sampah jika dibuang ke sungai dapat menimbulkan pencemaran air, mengganggu ekosistem perairan, dan dapat menyebabkan banjir. Pembakaran plastik dapat menimbulkan polusi udara yang dapat merusak lingkungan dan kesehatan pernafasan. Oleh karena itu, diperlukan suatu pengelolaan yang tepat sehingga dapat mereduksi timbulan sampah yang dihasilkan oleh aktivitas sehari-hari

Rata-rata capaian reduksi sampah melalui kegiatan 3R di Kabupaten Lombok Timur mencapai $10 \%$ dari total timbulan sampah. Minimnya reduksi sampah yang dihasilkan masyarakat disebabkan kurangnya pengetahuan masyarakat mengenai cara pengolahan sampah, minimnya sarana prasarana 3R, keterbatasan sumber daya manusia, masih minimnya pelatihan 3R di masyarakat [1].

Kelayu Jorong merupakan salah satu Kelurahan yang terletak di Kecamatan Selong Kabupaten Lombok Timur Nusa Tenggara Barat. Secara administratif, Kelurahan Kelayu jorong memiliki luas $330 \mathrm{Ha}$ dengan jumlah penduduk sebesar 5.799 jiwa [2]. Bila satuan timbulan sampah $=2 \mathrm{~L} /$ orang/hari atau $0,4 \mathrm{~kg} /$ orang/hari, maka perkiraan jumlah sampah dari permukiman adalah $=(2 \times 5.799 / 1000) \mathrm{m}^{3} /$ hari $=11,6 \mathrm{~m}^{3} /$ hari atau setara dengan 2,32 ton/hari. Bila jumlah sampah dari sektor non-permukiman dianggap 50 $\%$ dari sampah permukiman maka setara dengan 1,16 ton/hari, maka total sampah yang dihasilkan 
di Kelurahan Kelayu Jorong $=17,4 \mathrm{~m}^{3}$ /hari, atau $=3,48$ ton/hari. jika diasumsikan sampah plastik sekitar $14 \%$ dari total produksi sampah, maka sampah plastik di Kelurahan Kelayu Jorong berkisar $2,4 \mathrm{~m}^{3} /$ hari atau 0,5 ton/hari.

Pengelolaan sampah di lokasi ini belum mendapat perhatian pemerintah setempat secara maksimal. Warga masyarakat banyak membuang sampah di sungai, membakar sampah dan menimbun sampah karena tidak memiliki Tempat Pembuangan Sementara (TPS). Tidak tersedianya pengelolaan sampah di Kelurahan Kelayu Jorong berkontribusi terhadap pencemaran lingkungan dan meningkatnya jumlah timbulan sampah seiring dengan bertambahnya penduduk setempat.

Salah satu bentuk implementasi kebijakan terkait pengelolaan sampah, pemerintah telah menetapkan target pengurangan dan pengolahan sampah, termasuk sampah plastik sebesar $20 \%$ dari total timbulan sampah pada tahun 2019. Penetapan target tersebut mempertimbangkan penyusunan skala prioritas jenis sampah plastik yang perlu ditangani terlebih dahulu seperti kantong plastik, styryofoam, bungkus makanan [3].

Teknologi daur ulang limbah plastik merupakan salah satu upaya terbaik dalam mereduksi timbulan sampah plastik di lingkungan. Salah satu teknologi yang bisa digunakan untuk mengurangi jumlah sampah plastik adalah mengkonversi sampah plastik menjadi bahan bakar cair. Limbah plastik yang dapat menyebabkan pencemaran lingkungan dapat diolah menjadi energi menggunakan teknologi cracking atau perengkahan. Perengkahan yang terjadi pada plastik merupakan pemutusan ikatan rantai karbon penyusun plastik [4]. Hasil penelitian menunjukkan bahwa total produk bahan bakar yang dihasilkan dari campuran material plastik berbahan polistirena, polipropilena, dan polietilena menggunakan metode thermal cracking adalah $66,86 \%$. Persentase lebih tinggi dihasilkan dari campuran ketiga polimer tersebut menggunakan teknologi catalytic cracking yakni penambahan katalis karbon aktif, arang, campuran $\mathrm{CaO}$ dan karbon aktif sebesar 82,43\%, $95,54 \%$ dan $75,50 \%$ [5]. Konversi termal campuran polietilena-tempurung kelapa menggunakan katalis zeolit alam melalui proses pirolisis katalitik mengahasilkan produk utama hidrokarbon rantai karbon $\mathrm{C}_{8}-\mathrm{C}_{12}$ [6]. Sampah plastik jenis PET dapat dikonversi menjadi bahan bakar menggunakan catalytic cracking bentonit menghasilkan $69,08 \%$ fraksi bensin [7]. Jika diasumsikan $50 \%$ dari limbah plastik dapat terurai menjadi hidrokarbon cair, maka potensi bahan bakar cair yang bisa dihasilkan dari timbulan sampah plastik masyarakat Kelurahan Kelayu Jorong berkisar $1,2 \mathrm{~m}^{3} /$ hari atau $1200 \mathrm{Liter} /$ hari.

Kegiatan ini merupakan salah satu upaya yang bertujuan untuk mendukung perwujudan implementasi kebijakan pemerintah terkait pengolahan sampah, disamping meningkatkan pemahaman dan keterampilan masyarakat Kelurahan Kelayu Jorong tentang pengolahan sampah, khususnya sampah plastik yang sulit terdegradasi menggunakan teknologi cracking.

\section{METODE KEGIATAN}

Kegiatan pengolahan sampah plastik metode cracking, merupakan program pengabdian bagi masyarakat yang dilaksanakan di Kelurahan Kelayu Jorong Lombok Timur. Kegiatan ini bekerjasama dengan dua mitra, yakni kelompok karang taruna Sapta Lestari dan kelompok remaja masjid Jami' Darul Muttaqin. Kedua kelompok mitra tersebut memiliki ruang lingkup kegiatan di bidang lingkungan hidup dan hubungan masyarakat [2]. Adapun peran mitra pada kegiatan pengabdian adalah menyediakan dan mempersiapkan tempat/fasilitas yang dibutuhkan selama kegiatan penerapan ipteks bagi masyarakat (mitra IbM) berupa kegiatan pengolahan sampah plastik.

Kegiatan transfer teknologi kepada kedua mitra di Kelurahan Kelayu Jorong dilakukan dengan metode sosialisasi dan praktek. Dua metode ini diterapkan pada beberapa tahapan kegiatan antara lain: 1) pengelolaan sampah khususnya sampah plastik. Kegiatan ini dilakukan di tingkat keluarga, RT/RW dengan cara memilah sampah plastik dari jenis sampah lainnya dan mengumpulkannya pada wadah yang tersedia, 2) pengolahan sampah plastik menjadi bahan bakar cair menggunakan metode cracking, 3) analisis kualitas komponen bahan bakar cair yang dihasilkan dari metode cracking.

\section{HASIL DAN PEMBAHASAN}

Kegiatan sosialisasi bertujuan untuk memberikan pemahaman kepada masyarakat terkait pengelolaan sampah rumah tangga khususnya sampah plastik dan bagaimana mengolah sampah plastik menggunakan metode cracking sehingga dihasilkan produk bermanfaat. Kegiatan sosialisasi diikuti oleh perangkat Kelurahan Kelayu Jorong dan peserta terdiri atas dua kelompok mitra yang merupakan perwakilan dari warga masyarakat setempat.

Kegiatan sosialisasi dilakukan menggunakan metode ceramah dan tanya jawab. Deskripsi ipteks yang ditransfer kepada kedua mitra yakni terkait pengelolaan sampah di tingkat keluarga atau RT/RW. Pengelolaan sampah yang dilakukan mengacu pada Standar Nasional Indonesia (SNI) tentang pengelolaan sampah di permukiman yang terdiri atas kegiatan 
mengumpulkan dan memilah sampah berdasarkan jenisnya [6]. Selain itu, deskripsi ipteks tentang pengolahan sampah plastik menggunakan metode cracking juga disampaikan pada kegitan sosialisasi. Prinsip dasar metode cracking sampah plastik adalah mengubah senyawa polimer plastik menjadi komponen penyusunnya melalui pemutusan ikatan kimia pada temperatur tinggi.

Upaya peningkatan pemahaman kedua mitra terhadap materi yang sudah dipaparkan pada kegiatan sosialisasi, diaplikasikan menggunakan metode praktek. Praktek pengelolaan sampah yang dilakukan antara lain:

a. Menyediakan 3 wadah sampah terdiri atas wadah sampah organik, wadah sampah anorganik berupa plastik, dan wadah sampah anorganik lainnya

b. Memilah sampah sesuai jenis sampah. Sampah organik dan anorganik dimasukkan langsung ke masing-masing wadah

c. Memasang alat pengomposan rumah tangga (jika tersedia)

d. Memasang alat cracking untuk sampah anorganik plastik

Kegiatan pengelolaan sampah yang terdiri atas pemilahan dan pewadahan sampah dirasakan sangat penting oleh masyarakat Kelurahan Kelayu Jorong. Hal ini disebabkan karena sebagian besar masyarakat umumnya mempunyai kebiasan tidak baik dalam pengelolaan sampah yakni membuang sampah ke sungai, dibakar, dan bahkan memindahkan sampah rumah tangga ke areal kebun milik warga.

Wadah sampah didesain sedemikian rupa tergantung jenis sampah. Jenis sampah anorganik didesain menggunakan kotak persegi ukuran $40 \mathrm{x}$ 40 x $50 \mathrm{~cm}$ dilengkapi tutup, diperuntukkan untuk sampah anorgaik daur ulang dan guna ulang. Jenis sampah organik dibuat menggunakan planter bag diameter $40 \mathrm{~cm}$ supaya mudah dibawa dan mudah dicuci ketika terjadi pembusukan sampah.

Kegiatan pemilahan sampah dilakukan terhadap sampah individu (rumah tangga). Hasil pemilahan sampah di beberapa rumah tangga yang menjadi perwakilan masyarakat Kelurahan Kelayu Jorong menunjukkan komposisi sampah organik adalah sampah dominan yang terdapat di lokasi. Hal ini didukung oleh kondisi wilayah merupakan daerah pertanian dan perkebunan. Komposisi sampah plastik berada di urutan kedua. Jenis sampah plastik yang banyak ditemukan seperti kantong plastik, kemasan air minum, kemasan makanan, perabot rumah tangga, dan lain-lain. Komposisi sampah rumah tangga Kelurahan Kelayu Jorong dapat dilihat pada Gambar 1.

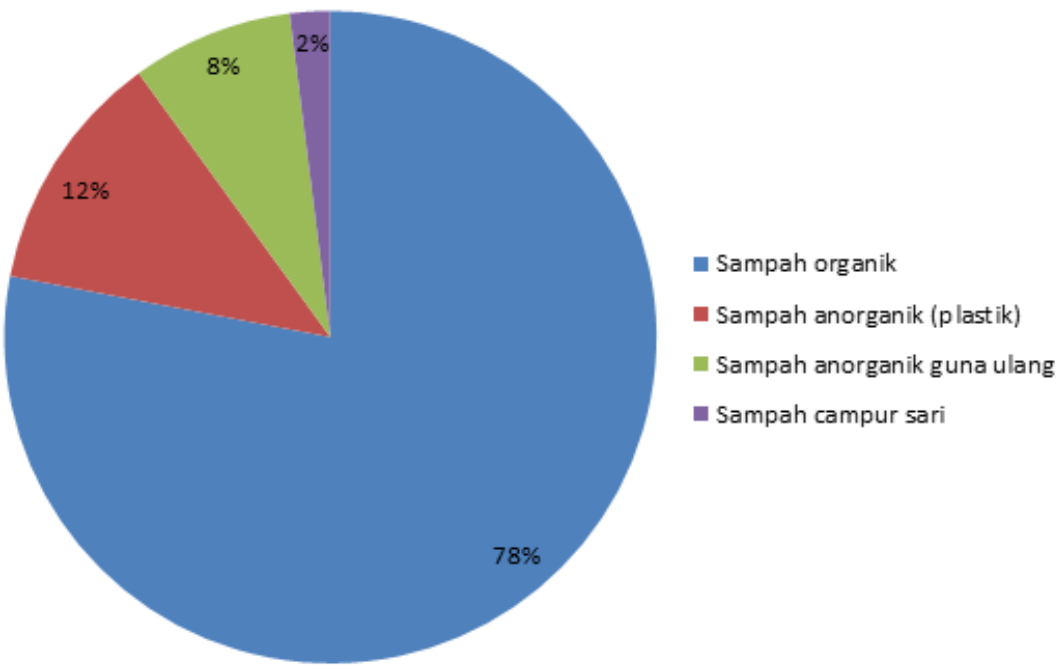

Gambar 1. Komposisi Sampah di Kelurahan Kelayu Jorong

Sampah rumah tangga yang sudah dipilih dan diwadahi berdasarkan jenisnya selanjutnya diolah dengan metode tertentu sesuai kebutuhan. Metode pengomposan dilakukan terhadap sampah organik. Selain itu juga, sampah organik bisa dikubur untuk menggemburkan tanah. Metode cracking dilakukan untuk mengolah sampah plastik.

Penerapan teknologi cracking bisa dilakukan dengan metode thermal cracking dan catalytic cracking. Kedua metode ini akan menghasilkan tiga jeni produk berupa gas, bahan bakar cair, dan residu. Ada tiga komponen utama pada desain alat cracking pada antara lain: 1 ). Wadah cracking atau reaktor, terbuat dari tabung gas LPG. Wadah tidak boleh mengalami kebocoran. Wadah ini berfungsi sebagai tempat berlangsungnya proses cracking atau perengkahan sampah plastik sesuai temperatur yang digunakan. Proses pemanasan pada temperatur tinggi menyebabkan sampah plastik mengalami perubahan fase dari padatan menjadi cairan atau lelehan. Fase ini selajutnya akan berubah menjadi fase gas. 2). Kolom fraksinasi, terbuat dari pipa baja dengan panjang $30 \mathrm{~cm}$. Pada 
kolom fraksinasi terjadi pemanasan yang berbedabeda di setiap plat yang terdapat di dalam kolom. Komponen yang terkandung pada sampah plastik dengan titik didih lebih tinggi, berupa cairan dan akan turun ke bawah. komponen titik didih rendah akan menguap dan naik ke bagian atas. Makin ke atas, suhu kolom fraksinasi makin rendah sehingga menyebabkan komponen dengan titik didih lebih tinggi akan mengembun dan terpisah sedangkan komponen dengan titik didih lebih rendah naik ke bagian atas kolom. 3). Kondensor, terbuat dari pipa baja yang dilengkapi dengan aliran pendingin. Kondensor berfungsi sebagai pipa penerima aliran uap dari kolom fraksinasi untuk diubah menjadi fase cair. Hasil cracking sampah plastik berupa bahan bakar cair. Bahan bakar cair hasil cracking selanjutnya dianalisa menggunakan instrumen Gas Chromatography-Mass Spectroscopy (GC-MS). Hal ini bertujuan untuk mengetahui komponen penyusun utama bahan bakar yang dihasilkan.

Tabel 1. Komposisi kandungan bahan bakar hasil cracking sampah plastik

\begin{tabular}{cccc}
\hline Fraksi & Komponen & Temperatur $\left({ }^{\circ} \mathrm{C}\right)$ & Konsentrasi $(\%)$ \\
\hline I & Bensin ringan & $<90$ & 5,42 \\
II & Bensin & $90-175$ & 29,99 \\
III & Bensin berat & $175-200$ & 23,30 \\
IV & Minyak tanah, solar & $>200$ & 8,18 \\
V & Residu & $>200$ & 33,15 \\
\hline
\end{tabular}

Berdasarkan hasil GC-MS, fraksi bensin adalah komponen utama yang terkandung dalam bahan bakar, yakni sebesar 58,81\%. Residu berupa campuran paraffin dan aspal sebesar $33,15 \%$. Hal ini menunjukkan bahwa sampah plastik memiliki potensi besar sebagai bahan baku energi alternatif berupa bahan bakar.

\section{KESIMPULAN}

Kegiatan alih teknologi kepada kelompok karang taruna Sapta Lestari dan kelompok remaja masjid Darul Muttaqin berjalan lancar. Ada dua kegiatan utama yang dilakukan yakni 1) pengelolaan sampah rumah tangga khususnya sampah plastik yang terdiri atas kegiatan pemilahan dan pewadahan sampah berdasarkan jenisnya, 2) pengolahan sampah plastik menjadi bahan bakar cair menggunakan metode cracking Adapun komponen utama dari bahan bakar cair yang dihasilkan berupa fraksi bensin sebesar 58,8 \%. Dengan demikian adanya teknologi cracking untuk mengolah sampah plastik menjadi bahan bakar cair diharapkan mampu mereduksi jumlah sampah plastik yang ada di masyarakat.

\section{UCAPAN TERIMA KASIH}

Penulis mengucapkan terima kasih kepada pihak DP2M KEMENRISTEK-DIKTI yang telah memberikan dukungan dana kegiatan pengabdian Ipteks bagi Masyarakat (IbM) tahun 2017. Ucapan terima kasih juga disampaikan kepada LPPM Universitas Mataram yang menjadi wadah penyelengara kegiatan penelitian dan pengabdian masyarakat. Apresiasi setingi-tingginya disampaikan kepada masyarakat Kelurahan Kelayu Jorong atas kerjasama dan dukungannya selama penyelenggaraan kegiatan transfer Ipteks sehingga kegiatan berjalan lancar dan tertib.

\section{DAFTAR PUSTAKA}

[1] Pokja Sanitasi Provinsi Nusa Tenggara Barat. 2014. Roadmap Sanitasi Provinsi Nusa Tenggara Barat Tahun 2015-2019. Pemerintah Provinsi Nusa Tenggara Barat. Mataram

[2] Kelurahan Kelayu Jorong. 2016. Profil Kelurahan Kelayu Jorong 2015. Pemerintah Kabupaten Lombok Timur

[3] Kementrian Lingkungan Hidup dan Kehutanan. 2015. Rangkaian HLH 2015- dialog penanganan sampah plastik.. http://www.menlh.go.id, diakses tanggal 2 Januari 2016

[4] Ermawati, R., 2011. Konversi Limbah Plastik Sebagai Sumber Energi Alternatif. Jurnal Riset Industri, 5, 3 : 257-263

[5] Kumar, P.S., Bharatikumar, M., Prabhakaran, C., Vijayan, S., Ramakrishnan, K., 2017. Conversion of waste plastics into lowemissive hydrocarbon fuels through catalytic depolymerization in a new laboratory scale batch reactor. International Journal of Energy and Environmental Enginnering. 8: 167.

[6] Windari, T. \& Suseno, A., 2011. Konversi Termal Campuran Polietilena- Tempurung Kelapa Menjadi Hidrokarbon Cair. Jurnal Sains dan Matematika, 19, 2, 43-46

[7] Standar Nasional Indonesia Nomor SNI 3242:2008. Pengelolaan Sampah di Permukiman. Badan Standar Nasional BSN.Jakarta 